SEMINARL

Mazurowski 1
NeK"

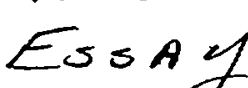

John E. Mazurowski, Lt Col, USAF

Colonel McNamara

Course II

6 November 1992

Staff Officer's Journal from the second Gulf War of 2001 Preface

The following excerpts from Colonel Jack Smith's war journal as the US Central Command (USCENTCOM) Policy and Strategy Division Chief during the most recent Arabian Gulf conflict are unique in many respects. First, as a veteran of USCENTCOM's War Plans Division during the First Gulf war of 1991, he provides several insights into how General Schwarzkopf's staff operated during the fog of that war. Secondly, his analysis of the Desert Storm campaign plan's war termination objectives in relation to the strategy framework outlined by Sir Basil Liddell Hart and Colonel John Taylor clearly shows why we have ended up deploying huge numbers of troops to the Arabian Peninsula for the second time in ten years. Finally, his recommendations to insure military force is used to foster a lasting peace deserve consideration by the leaders who fashion our national policy.

\title{
Journal Excerpts
}

2 August 2001. I still can't believe Saddam Hussein came south again! But, you have to hand it to the thug - this time, not only was he bright enough to initially bypass Kuwait with a two-pronged attack on the city of Riyadh and the critical oil processing and export facilities in the Eastern Province, but he 


\section{Report Documentation Page}

Form Approved

OMB No. 0704-0188

Public reporting burden for the collection of information is estimated to average 1 hour per response, including the time for reviewing instructions, searching existing data sources, gathering and maintaining the data needed, and completing and reviewing the collection of information. Send comments regarding this burden estimate or any other aspect of this collection of information,

including suggestions for reducing this burden, to Washington Headquarters Services, Directorate for Information Operations and Reports, 1215 Jefferson Davis Highway, Suite 1204, Arlington

VA 22202-4302. Respondents should be aware that notwithstanding any other provision of law, no person shall be subject to a penalty for failing to comply with a collection of information if it

does not display a currently valid OMB control number.

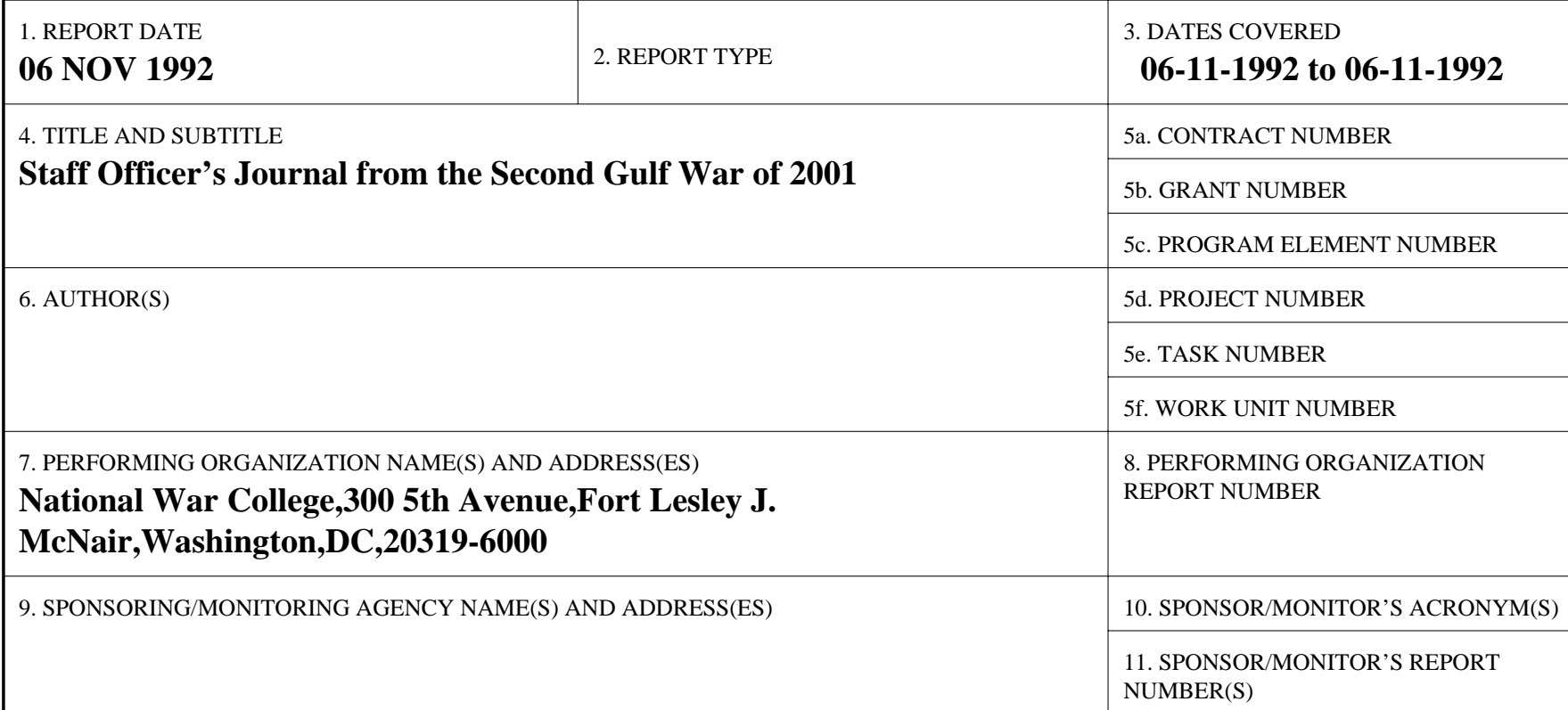

12. DISTRIBUTION/AVAILABILITY STATEMENT

Approved for public release; distribution unlimited

13. SUPPLEMENTARY NOTES

14. ABSTRACT

see report

15. SUBJECT TERMS

16. SECURITY CLASSIFICATION OF:

a. REPORT

unclassified b. ABSTRACT

unclassified c. THIS PAGE

unclassified
17. LIMITATION OF ABSTRACT
18. NUMBER OF PAGES

8 19a. NAME OF RESPONSIBLE PERSON 
Mazurowski 2

also had a warped sense of history by invading exactly ten years to the day after starting the First Gulf War. I guess our first clue that saddam had a better grasp on western thinking should have been his refusal to accept any more intrusive United Nations' inspections shortly after Bill Clinton took office in 1993. Clinton, anxious to prove he could be an effective Commander in Chief, ordered USCENTCOM to implement its air contingency plans to force Iraqi compliance. Since there were no clear national or coalition objectives for the air attacks, however, they proved to be more effective propaganda material for Saddam than anything else. The resulting Arab backlash had forced us to bring all of our troops home from every Arabian Gulf state except Kuwait. Consequently, we simply didn't have enough force in theater to deter or stop today's attack.

4 August 2001 . On the road to USCENTCOM Forward again in the back of a C-141. Since Riyadh has fallen, however, our destination this time is Muscat, Oman. Too bad - the Saudi Ministry of Defense and Aviation in Riyadh, built by the us Army Corps of Engineers, had been a perfect headquarters. Somehow, I don't think Muscat will be the same. Some things never change, though, these troop seats are still uncomfortable as hell!

5 August 2001 . Have to hit the ground running since our current war plan essentially fought the First Gulf war over again. Without access to all those beautiful airfields and ports in Saudi Arabia, we're going to have to build a whole new concept. Hope the fax comes through quickly from Washington on 
Mazurowski 3

the revised national policy objectives - it will be critical to building a military strategy with sound war termination objectives. One question keeps nagging me, though - how could all this have happened so quickly when America's hero, General Schwarzkopf, said in his best-selling book, "For once, we were strategically smart enough to win the war and the peace?"

5 August 2001. Murphy's Law hits again - the airplane is broke here at Lajes and needs an engine change. Oh well, at least this will give me some time to think through what could have gone wrong during the First Gulf war while I'm waiting in the airport terminal. I sure am glad that the year at the National War College provided me a sound framework for analyzing military strategy.

In particular, I'll never forget reading what Liddell Hart said about war:

The object of war is to attain a better peace - even if only from your own point of view. Hence it is essential to conduct war with constant regard to the peace you desire. . . If you concentrate exclusively on victory, with no thought for the after-effect, you may be too exhausted to profit by the peace, while it is almost certain that the peace will be a bad one, containing the germs of another war. This is a lesson supported by abundant experience.

This passage makes such good common sense, yet, it applies to just about every war the Us has fought, and especially to the First Gulf War. Where did we gone wrong?

Let's start with the salient US national policy objectives for the war: immediate, complete, and unconditional withdrawal of all Iraqi forces from Kuwait; restoration of Kuwait's 
Mazurowski 4

legitimate government; and maintenance of security and stability for Saudi Arabia and the Arabian Gulf. Subsequently, USCENTCOM translated these objectives into the following military aims for the campaign plan: neutralize Iraqi National Command Authority; eject Iraqi armed forces from Kuwait; destroy the Republican Guard; destroy Iraq's known nuclear, biological, and chemical capability; and assist in restoring the legitimate government of Kuwait.

Many have since argued that these national objectives and military aims were clearly stated and completely in accord with one another. In fact, Colonel Harry Summers, Ret., wrote in on Strategy II: A Critical Analysis of the Gulf war, that the objectives were so well done that it was positive proof that we had learned the primary lesson of the vietnam war. I disagree. Closer analysis indicates the national objectives would only lead to reestablishing the status quo, a situation which had already broken down once and led to war. Furthermore, while Iraq's ability to project external power through weapons of mass destruction and the Republican Guard had been seriously damaged, it clearly would only be a matter of time before this ability would resurface with Saddam and Iraqi scientific brainpower still intact.

Further analysis using the following statement from colonel John Taylor's essay, "Military Strategy: How to Think About It," illustrates the problem from the national level:

An objective that simply says 'security and stability in the region' is inadequate for strategic military 
planning. More specificity is required. Military strategists should know, for example, what borders might be changed, what future international relationships are desired, and what economic, political, and social conditions are desired in the post-war world. The military strategist's analysis of those conditions should dictate how the military instrument of power will be employed.

Clearly, this applies directly to President Bush's national objective for maintaining security and stability in Saudi Arabia and the Arabian Gulf. Through dialogue with the state Department and Joint Staff, our Policy and Strategy Division was gradually able to formulate answers to the above specific questions. For example, the endgame became to keep Iraqi borders intact to halt any spread of Islamic fundamentalism from Iran and to insure Shi'ite and Kurdish minorities would not cause political problems for neighboring Gulf states and Turkey. Also, when coalition Arab leaders said they could still live with saddam after a war, our strategy evolved into destroying Saddam's ability to project external power, strengthening the Gulf Cooperation Council (GCC) into an effective collective security organization with the support of military forces from Egypt and syria, and prepositioning sufficient armor on the Arabian Peninsula to thwart any future Iraqi attack.

In my opinion, however, not all of the problems stemmed from the national level - indeed, the USCENTCOM/J-5 must accept responsibility for several disconnects in military strategy. For example, we should have recognized very early that a strategy of collective security through the GCC would never work, mainly because we had eliminated the one major unifying factor of a 
Mazurowski 6

strong external military threat from Saddam Hussein. Why did this happen? First of all, the Policy and Strategy Division was not organized very well. Since most of the division was manned by ex-planners from the War Plans Division, they didn't have the required experience to effectively work critical policy issues only two months before the start of a war. Secondly, our Political-Military Division had become almost totally immersed in planning for the late-arriving civil affairs forces in theater and could not devote the same amount of attention to politicalmilitary questions as it had in the past. Overall, I'm convinced better organization would have made for a more coherent military strategy.

6 August 2001. The airplane is fixed! Finally, back on the road again. So there's only one question left to reflect on before landing - what could we have done to improve our performance during the First Gulf war? First, I think we should have added more policy and strategy experts to the staff to actively question guidance and formulate alternatives in the interest of a long-term peace. In the War Plans Division, we had been augmented with the expertise of four of the best graduates from the Army's School of Advanced Military Science and four experienced deception planners from the Air and Army Staffs. The Policy and Strategy Division was augmented by one individual - an instructor from west point who had originally deployed to our Army component as a communications expert. The bottom line is that the majority of attention and plus-up in manpower expertise 
went to the War Plans Division. Command emphasis was clearly on insuring military victory via a sound campaign plan and not on the issue of thinking about the long-term peace - even Schwarzkopf's book was $95 \%$ about winning the war and $5 \%$ on winning the peace. I'll have to talk with the J-5 about this as soon as possible after landing - we have to get the national objectives and military aims absolutely right this time before the campaign plan is written.

Secondly, we can't hesitate to take the Joint staff and State Department to task when we receive incomplete guidance. Several examples from the last war come to mind. To begin with, the "security and stability in Saudi Arabia and the Arabian Gulf" objective should have been challenged right away since it says nothing about how military forces ought to be employed to achieve a long-term peace. Although we developed several military aims to support this objective, they were clearly just temporary measures that contained the seeds for the next war - just like Liddell Hart had predicted. Furthermore, the strategy to maintain Iraq as an integral country should also have been questioned. While this policy stemmed from our coalition friends' fear of the potential destabilizing affect of a shi'ite or Kurdish state, I think we should have explored other alternatives in greater depth. Another passage from Liddell Hart is instructive:

Vitality springs from diversity - which makes for real progress so long as there is mutual toleration, based on the recognition that worse may come from an attempt to suppress differences than from acceptance of them. 
For this reason, the kind of peace that makes progress possible is best assured by the mutual checks created by a balance of forces - alike in the sphere of internal politics and of international relations.

To create this kind of diversity in Iragi politics would have required a bold effort on the part of the world community and coalition militaries, but wouldn't that have been better and cheaper in the long run than doing this all over again ten years later?

7 August 2001 . Stepping off the airplane at Muscat quickly reminded me how incredibly hot the desert is here. So far, our Omani hosts have been extremely cordial in helping us set up our new offices - must be the British influence. However, I still can't get over reading the first fax that came through on our new national policy objectives - the last one read "promote security and stability in Oman, Saudi Arabia, and the Arabian Gulf." Can you believe that? Guess I have my work cut out for me.

\section{Postscript}

Unfortunately, Colonel Jack Smith did not get a chance to follow through on his ideas. A highly accurate SCUD-D variant, developed by Saddam's scientists in cooperation with the Chinese over the last ten years, exploded at the USCENTCOM compound in Muscat killing him and fifty other members of the advance staff. The above excerpts from his journal were sent to the Joint Policy Review by his widow, who thought they might be of some value in obtaining a real long-term peace from our continuing involvement in Southwest Asian affairs. 